\title{
CONSUMERS' INTENTION TO STAY IN GREEN HOTELS IN SOUTH AFRICA: THE EFFECT OF ALTRUISM AND GREEN SELF-IDENTITY
}

\author{
Olawale FATOKI* \\ University of Limpopo, Department of Business Management, Private Bag X1314, Sovenga, 0727, South Africa, e-mail: olawale.fatoki@ul.ac.za
}

\begin{abstract}
Citation: Fatoki, O. (2020). CONSUMERS' INTENTION TO STAY IN GREEN HOTELS IN SOUTH AFRICA: THE EFFECT OF ALTRUISM AND GREEN SELF-IDENTITY. GeoJournal of Tourism and Geosites, 32(4), 1310-1316. https://doi.org/10.30892/gtg.32418-574
\end{abstract}

\begin{abstract}
The aim of the study was to investigate the effect of the extended Theory of Planned Behaviour (TPB) model that included two personal factors (altruism and green self-identity) on consumer intention to stay in green hotels. First, the study examined how the individual construct of the TPB model affected consumer intention to stay in green hotels. Second, the study investigated how the extend ed TPB model that included two personal factors (altruism and green self-identity) affected consumer intention to stay in green hotels. Third, the study examined if attitude towards green hotels mediated the relationship between altruism and green self-identity and intention. The study adopted the quantitative research design and the cross-sectional survey method was used for data collection. The Partial Least Square Structural Equation Modelling (PLS SEM) was used for data analysis. Based on a dataset of 416 respondents, the results confirmed the applicability of the TPB model in predicting consumer intention to stay in green hotels in South Africa. The inclusion of altruism and green self-identity increased the predictive power of the TPB model. Additionally, the study found a partial mediation effect of attitude in the relationship between altruism and intention. The mediating effect of attitude in the relationship between green self-identity and intention is insignificant.
\end{abstract}

Key words: Theory of planned behaviour, green hotels, altruism, green self-identity, South Africa

\section{INTRODUCTION}

Rapid economic growth in many developing and developed countries has led to many negative effects such as the overuse of resources, pollution and environmental degradation. There is a growing acceptance that one of the most important challenges faced by the world is climate change (Alvarado and Toledo, 2017; Ali and Oliviera, 2018). Individual and business behaviour and action related to consumption are one of the causes of these ecological issues (Noor et al., 2014; Constant, 2019; Rahman, 2020). Growing awareness of sustainable development is driving individuals and businesses to shift to sustainable consumption and business models. The United Nations Sustainable Development Goal number 12 focuses on the use of sustainable production and consumption by individuals, businesses and governments to increase resource efficiency, promote sustainable lifestyle and reduce environmental degradation (Pradhan et al., 2017; Folarin and Adeniyi, 2020).

Despite their positive contributions, hotels are associated with high emissions of greenhouse gases, heavy consumption of natural resources and substantial production of waste with damaging effects on the environment (Alipour et al., 2019; Karim and Islam, 2020; Kurniawati et al., 2020). Hotels have started to pay attention to environmental issues due to increased stakeholder pressure especially from customers and governments. Subsequently the implementation of green initiatives is increasing in hotels in order to reduce negative environment impact and associated costs, attract and retain customers, sustain competitive advantage and ultimately improve financial performance (Chan et al., 2018; Mbasera et al., 2018; Chivandi et al., 2020). This has stimulated the development of green hotels described as lodging establishments that are committed to ecologically sound practices (Han et al., 2010). Green hotels are a growing niche in the current South Africa's competitive hospitality industry but progress is limited and many hotels are still conventional (Hoogendoorn et al., 2015). One of the ways to distinguish green hotels from conventional hotels is certification which can be described as a voluntary process by an organisation that assesses and gives written assurance that a product, process or facility meets specific standards and awards a marketable logo (Honey and Rome, 2011).

Spenceley (2018) in a study on sustainable tourism certification in the African hotel sector finds that only 153 hotels in South Africa have been awarded green certification. According to Nimri et al. (2019), consumers have displayed conflicting interests in green hotels. Although there is a high media publicity about environmental issues and green hotels, many consumers still consider environme ntalism as an issue of low importance and are reluctant to voluntarily change their consumption choices (Burke et al., 2018). In addition, empirical studies that focus on consumer/traveller behaviour in relation to green hotels are limited. A review of green resea rch in hospitality (2000-2014) by Kim et al. (2017) revealed that out of 146 empirical papers, only 37 (25.3\%) focused on consumers while the majority 61 or $(41.8 \%)$ were management cantered. Furthermore, Nimri et al. (2019) remark that a theoretically-driven perspective to exploring the formation of consumer behaviour towards staying in green hotels is limited and should be expanded. This will help to advance knowledge about the determinants of consumer intention to stay in green hotels.

The Theory of Planned Behaviour (TPB) by Ajzen (1991) is the dominant model of intention formation and has been used by studies on intention to stay in green hotels (Chen and Tung, 2014; Manosuthi et al., 2020). The TPB is open to modification and can be deepened and broadened by the addition of new variables as long as they will improve the explanatory power of the model (Ajzen, 1991). The extended versions of the TPB have been to explore the intention to stay in green hotels (Suki and Suki, 2015; Verma and Chandra, 2017). One of the criticism of the TPB is that it does not include, personal norms, affects and emotions (Wolff et al., 2011). Altruism is related to personal norm as it involves the act of doing something good for other people without expecting anything in return (Nguyen et al., 2017). Furthermore, self-identity is a personal factor that can be used explain pro-environmental intention and behaviour (Gatersleben et al., 2014). However, studies that have used altruism and green self-identify to investigate consumer intention to stay in green hotels in developing countries are scarce. In addition, Carlo et al. (2005) point out that the relationship between personality traits (e.g. altruism) and behaviour can be better explained by examining the role of a mediating variable. Attitude may mediate the relationship between personality variables such as altruism and pro-environmental behaviour because some unique psychological resources of an individual

\footnotetext{
${ }^{*}$ Corresponding author
} 
may lead to behaviour modification. Gatersleben et al. (2014) remark that although researchers have used self-identity to extend the TPB, however, research is inconclusive about the role of self-identity in the TPB structure. There are conflicting findings about whether selfidentity has a direct effect or an indirect effect on intention and behaviour through attitude (Sparks and Shepherd, 1992). To the best of the author's knowledge, this is the first study that will examine the mediating effect of attitude in the relationship between altruism and green self-identity from the context of consumer intention to stay in green hotels.

Therefore, the objectives of the study are threefold. First, the study will examine how each construct of the TPB model affects consumer intention to stay in green hotels. Second, the study will investigate the effect of the extended TPB model that includes altruism and green self-identity on consumer intention to stay in green hotels. Third, the study will examine if the relationship between altruism and green self-identity and intention can be mediated by attitude.

\section{LITERATURE REVIEW AND DEVELOPMENT OF HYPOTHESES}

\section{Green hotels}

Verma and Chandra (2017) point out that the hospitality industry has adopted ecologically-friendly initiatives because of growing concern about the environment by customers and other stakeholders. This has led to the development of green hotels. Chen and Chen (2012: p 212) describe a green hotel as a hotel "with the goal to introduce the idea of environmental protection into either hotel hardware or software in order to save energy and reduce wastes". Hardware refers to the construction of the hotel and the main physical facilities while software describes the employees and the operational processes. According to Han et al. (2010), green hotels are lodging establishments that are committed to ecologically sound practices Some of the features of a green hotel include green construction, green purchasing, energy saving, recycling and well trained employees and management about eco-friendly practices (Chen and Chen, 2012; Verma and Chandra, 2017).

\section{Theory of planned behaviour}

The Theory of Planned Behaviour (TPB) is an extension of the Theory of Reasoned Action (TRA) (Ajzen and Fishbein, 1980; Ajzen, 1991). The TRA contends that an individual's intention to perform a behaviour is the main determinant of whether he/she actually performs the behaviour. This is because such behaviours are volitional and under the control of intention. The TRA argues that behavioural intention is influenced by two factors namely attitude towards performing the behaviour and subjective norms (Ajzen and Fishbein, 1980). The TPB extends the TRA by adding perceived behavioural control as one of the predictors of intention (Ajzen, 1991). The TPB stipulates that the performance of a specific behaviour by an individual is determined by the intention which depends on attitude, subjective norms and perceived behavioural control (Ajzen, 1991). Attitude towards the behaviour measures the degree to which an individual has a favourable or an unfavourable evaluation of the behaviour being measured. Subjective norms measure the likelihood that important reference individuals or groups such as friends and family will approve or disapprove the performance of a particular behaviour. Perceived behavioural control can be described as the perceived difficulty or ease of conducting a behaviour (Ajzen, 1991). Farrow et al. (2017) point out that after a general explanation of what constitutes subjective norms, the difference between injunctive and descriptive norms becomes an important area of distinction. Injunctive norms describe what significant others think that an individual ought to do while descriptive norms refer to what significant others themselves do (Doran and Larsen, 2016).

The TPB has been used to examined consumer intention to visit green hotels. Han et al. (2010) used the TPB to examine the intention of customers to visit green hotels. The population for this study was lodging customers in the United States of America (USA). The findings of the study indicated that the TPB model has a good predictive power with the three TPB constructs positively affecting the intention to stay in a green hotel. Teng et al. (2015) in a Taiwanese study also find that customer behavioural intention to stay in a green hotel is predicted by the three TPB constructs with subjective norms having the biggest effect. The findings of a study by Shen (2017) on consumer intention to dine in green restaurants in Taiwan also support the applicability of the TPB model with the three cons tructs having significantly positive effects. The study by Suki and Suki (2015) explored the relationship between returning tourists' propensity to stay in green hotels in Malaysia and find significant positive effects of attitude and perceived behavioural control.

However, the impact of subjective norms is not significant. In addition, Verma and Chandra, 2017 in an Indian study and Nimri et al. (2019) in an Australian study strongly validate the applicability of the TPB model and find significant positive relationship s between the three TPB constructs and consumer intention to stay in green hotels. An examination of the empirical studies discussed above showed that they have focused mainly on USA, and Asia. There is a dearth of studies with an African focus. However, on the basis of theoretical and empirical evidence, the following hypotheses are developed.

Hypothesis 1: Attitude towards green hotels has a significant positive effect on customer intention to stay in green hotels.

Hypothesis 2: Subjective injunctive norms have a significant positive effect on customer intention to stay in green hotels.

Hypothesis 3: Subjective descriptive norms have a significant positive effect on customer intention to stay in green hotels.

Hypothesis 4: Perceived behavioural control has a significant positive effect on customer intention to stay in green hotels.

\section{Altruism and intention to stay in green hotels}

Altruism is a personal value structure with significant influences on behaviour and it involves concern about the welfare of society and others (Teng et al., 2015). The norm-activation theory by Schwartz (1977) depicts altruism in the context of environmental concern. The theory argues altruistic individuals tend to internalise responsibility for the welfare of others and this can affect attitude towards proenvironmental behaviour. The findings of empirical studies on the relationship between altruism and pro-environmental behaviour are inconclusive. Ryan (2017) in a study on the effect of altruism on the intention to purchase green products in the USA finds a positive but insignificant direct relationship. Ojedokun (2011) investigated the effect of altruism on responsible environmental behaviour in Nigeria. The findings of the study revealed a significant positive relationship between altruism and responsible environmental behaviour. In the context of the intention to visit green hotels, Teng et al. (2015) in a Taiwanese study used altruism to extend the TPB. The findings indicated that altruism has a positive and significant effect on consumer intention to visit green hotels.

Some studies have examined the indirect effect of altruism on the intention to stay in green hotels. Tan et al. (2020) argue that when altruistic consumers find the stay in green hotels compatible with their altruistic value, they can develop a strong reason for patronage and this can drive behavioural intention. The study conducted in Malaysia found that reason for patronage mediates the relationship between altruism and consumer green hotel patronage intention. Ojedokun and Balogun (2010) in a study conducted in Nigeria find a significant positive relationship between altruism and attitude towards littering. In addition, Carlo et al. (2005) point out that the relationship between personality traits (e.g. altruism) and behaviour can be better explained by examining the role of mediating variable. Attitude may mediate the 
relationship between personality variables such as altruism and pro-environmental behaviour because some unique psychological resources of an individual may lead to behaviour modification. Ojedokun and Balogun (2010) find that attitude towards littering partially mediates the relationship between altruism and responsible environmental behaviour. Consequently, the following hypotheses are developed.

Hypotheses 5: There is a significant positive relationship between altruism and intention to stay in green hotels.

Hypothesis 6: Attitude towards green hotels positively mediates the relationship between altruism and intention to stay in green hotels.

\section{Green self-identity (GSI) and intention to stay in green hotels}

According to Lalot et al. (2019), green self-identity, describes the extent to which an individual perceive him/herself as an environmentalist. Self-identity is one of the constructs that can explain human behaviour and can be used to extend the TPB (Gatersleben et al., 2014). Research is inconclusive about the role of self-identity in the TPB structure and whether self-identity has a direct or an indirect effect on intention and behaviour through attitude (Sparks and Shepherd, 1992). Charng et al. (1988) argue that self-identity is already covered by attitude and the causal link from an individual's self-identity to behavioural intention cannot be independent of attitude. Other studies (Granberg and Holmberg, 1990) assert that self-identity can offer meaning to a behaviour that is independent of attitude towards performing the behaviour as long the behaviour supports the self-identify of the individual. Individuals with GSI may purchase environmentally friendly products and services because they are in congruence their self-definition needs (Qasim et al., 2019). Barbarossa et al. (2017) find that the effects of GSI on pro-environmental behaviour can be direct and indirect. GSI can have a direct impact on proenvironmental behaviour and individuals that perceive themselves as green consumers are more likely to engage in specific proenvironmental actions and behaviour that support their green self-identity role. With respect to the indirect effect, individuals that perceive themselves as green consumers are more likely to be concerned about the ecological effect of their consumption choices and more likely to perceive the moral obligation of pro-environmental behaviour leading to a stronger intention to use eco-friendly alternatives. Empirical studies (Carfora et al., 2017; Qasim et al., 2019) find a significant positive relationship between GSI and green intention and behaviour. An individual on the basis of expectation of him/herself can consume a product or service that aligns with their perceived identify. Therefore, GSI may significantly affect behavioural intention and behaviour. It is hypothesised that:

Hypotheses 7: There is a significant positive relationship between GSI and intention to stay in green hotels.

Hypothesis 8: Attitude toward green hotels positively mediates the relationship between GSI and intention to stay in green hotels.

Figure 1 depicts the conceptual model of the study.

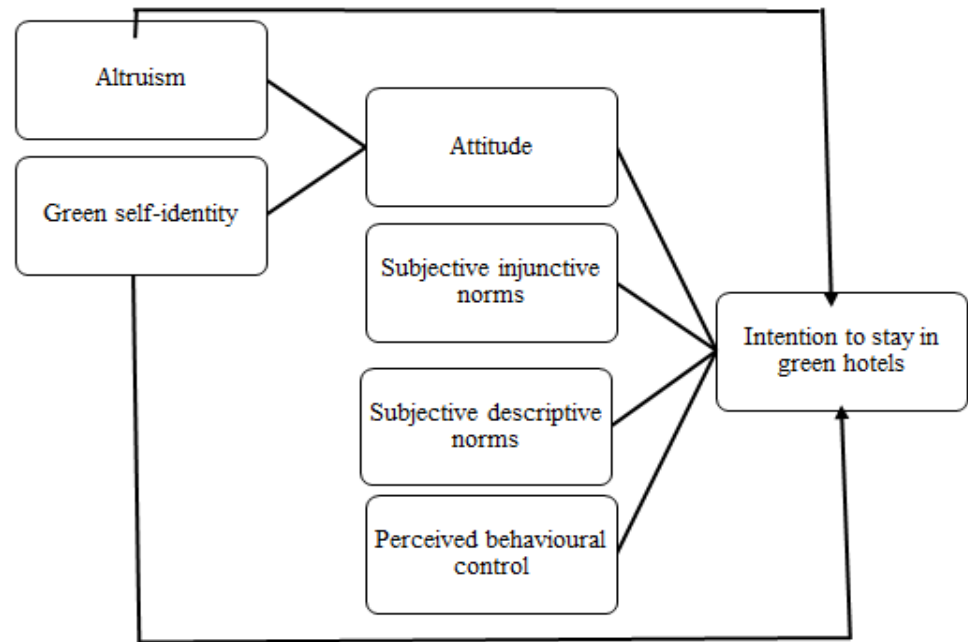

Figure 1.The conceptual model (author's conceptualisation)

\section{MATERIAL AND METHODS}

The study adapted the quantitative research design and the cross-sectional survey approach was used to collect data from the respondents. The respondents were random customers that came to stay in selected conventional hotels in Pretoria and Johannesburg and Polokwane in the Gauteng and Limpopo Provinces of South Africa. The Gauteng Province is the economic hub of South with Johannesburg being the largest city and Pretoria the administrative capital of the country. Many hotels are located in the two cities with many visitors. Polokwane is the economic hub of the Limpopo Province. The sample for the study includes all South African tra vellers who have stayed in conventional hotels and are aware of green hotels. The convenience sampling method was used to select hotels that are graded by the Tourism Grading Council of South Africa in the study area. The managers of seventy hotels were formally contacted through e-mailed letters to solicit for the participation of their hotels and visitors in the survey. Twenty hotels agreed to participate and fifty questionnaires were allocated to each hotel. Three trained field agents assisted with data collection. The privacy of hotel visitors was respected and only willing hotels and visitors were selected. To aid participation of hotels, the purpose and benefit of the study to the tourism industry were explained in a covering letter. Respondents were recruited by intercepting those visiting hotels.

Additional questionnaires were left in agreed places (dining rooms and reception halls) and collected after completion. Telephone numbers of contacts in the participating hotels were obtained. Confidentiality and anonymity were assured and the names of the hotels and visitors were not requested and not included in the questionnaire. The cover page of the questionnaire included a detailed description of a green hotel in order for respondents to get a good understanding of the concept. The survey was conducted between September and December 2019. Before actual data collection, the questionnaire was pretested with thirty respondents and the pilot study led to minor adjustments to improve content validity. The questionnaire was divided into two sections demographic and determinants of inte ntion to visit green hotels. The Partial Least Square Structural Equation Modelling (PLS SEM) was used for data analysis. 


\section{RESULTS AND DISCUSSION}

Response rate and biographical details

1000 questionnaires were distributed and four hundred and sixteen questionnaires were returned and usable by the end of December 2019. Eighteen questionnaires were not usable because the respondents failed to complete significant questionnaire items. The re were 231 male and 185 female respondents. The age distribution was as follows: 18-20 years, 17 respondents, 21-30, 62 respondents, 31-40, 145 respondents, 41-50 136 respondents, 51-60, above 60. 348 respondents have post Matric qualifications (diplomas and degrees) and 86 respondents have Matric qualification.

\section{Structural equation modelling}

The evaluation of the measurement model

The study followed the criteria by Hair et al. (2019) for the evaluation of the measurement model. These include the examination of factor loadings (>0.708), composite reliability (between 0.790 and 0.900), Cronbach's alpha (>0.700) and the AVE (minimum 0.500), Also, the square roots of the AVEs should be greater than the correlations amongst variables. The results as indicated by Table 1 showed that the composite reliability values for the constructs ranged between 0.811 and 0.875 . In addition, the Cronbach alpha coefficients for all the construct range between 0.728 and 0.826 indicating a satisfactory internal consistency of measures.

Table 1. The measurement model Data source (author's data analysis)

\begin{tabular}{|c|c|c|c|c|c|}
\hline Construct & Measurement items & Item loading & Cronbach's alpha & Composite reliability & AVE \\
\hline $\begin{array}{l}\text { Attitudes (ATT) } \\
\text { For me, staying in a green hotel when traveling is good }\end{array}$ & ATT1 & 0.836 & 0.826 & 0.857 & 0.600 \\
\hline For me, staying in a green hotel when traveling is desirable & ATT2 & 0.724 & & & \\
\hline For me, staying in a green hotel when traveling is pleasant & ATT3 & 0.804 & & & \\
\hline For me, staying in a green hotel when traveling is wise. & ATT4 & 0.729 & & & \\
\hline $\begin{array}{l}\text { Subjective injunctive norms (SIN) } \\
\text { Most people who are important to me would want me to stay in a green } \\
\text { hotel when travelling }\end{array}$ & SIN1 & 0.821 & 0.728 & 0.811 & 0.589 \\
\hline $\begin{array}{l}\text { Most people who are important to me think that I should stay in a } \\
\text { green hotel when travelling }\end{array}$ & SIN2 & 0.753 & & & \\
\hline $\begin{array}{l}\text { Most people who are important to me will want me to stay in a green } \\
\text { hotel when travelling even if it might be more expensive }\end{array}$ & SIN3 & 0.726 & & & \\
\hline $\begin{array}{l}\text { Subjective descriptive norms (SDN) } \\
\text { Most people whose opinion I respect will stay in a green hotel when travelling }\end{array}$ & SDN1 & 0.802 & 0.712 & 0.813 & 0.592 \\
\hline Most people that I consider important will stay in a green hotel when travelling. & SDN2 & 0.779 & & & \\
\hline $\begin{array}{l}\text { Most people that are important to me will stay in a green hotel when } \\
\text { travelling even if it might be more expensive }\end{array}$ & SDN3 & 0.726 & & & \\
\hline $\begin{array}{l}\text { Perceived behavioural control (PBC) } \\
\text { Whether or not I stay at a green hotel when traveling is completely up to me. }\end{array}$ & PBC 1 & 0.866 & 0.746 & 0.831 & 0.623 \\
\hline I am confident that if I want, I can stay at a green hotel when traveling. & PBC2 & 0.769 & & & \\
\hline $\begin{array}{l}\text { I have resources, time, and opportunities to stay at a green hotel when } \\
\text { traveling. }\end{array}$ & PBC3 & 0.726 & & & \\
\hline $\begin{array}{l}\text { Altruism (ALT) } \\
\text { I think that staying in a green hotel helps decrease pollution }\end{array}$ & ALT1 & 0.808 & 0.808 & 0.864 & 0.615 \\
\hline I think that staying in a green hotel helps conserve natural resource & ALT2 & 0.771 & & & \\
\hline I think that staying in a green hotel helps to mitigate global warming & ALT3 & 0.826 & & & \\
\hline I think that staying in a green hotel helps to protect the environment & ALT4 & 0.728 & & & \\
\hline $\begin{array}{l}\text { Green self-identity (GSI) } \\
\text { Acting environmentally friendly is an important part of who I am }\end{array}$ & GSI1 & 0.882 & 0.802 & 0.875 & 0.638 \\
\hline I am the type of person who acts environmentally friendly & GSI2 & 0.831 & & & \\
\hline I see myself as an environmentally friendly person & GSI3 & 0.744 & & & \\
\hline I can make significant changes in my lifestyle for environmental reasons & GSI4 & 0.727 & & & \\
\hline $\begin{array}{l}\text { Intention (INT) } \\
\text { I am willing to stay at a green hotel when traveling }\end{array}$ & INT1 & 0.842 & 0.728 & 0.834 & 0.623 \\
\hline I plan to stay at a green hotel when traveling. & INT2 & 0.801 & & & \\
\hline I will make an effort to stay at a green hotel when traveling & INT3 & 0.728 & & & \\
\hline
\end{tabular}

This implies an acceptable level of construct validity. The AVEs ranged between 0.589 and 0.638 suggesting a good convergent validity of the scales. The Fornell and Larcker criteria was used to assess discriminant validity. The results as depicted by table 2 showed that the square roots of AVEs are depicted on the diagonals are greater than the corresponding correlation coefficients within the constructs. It can be concluded that the measurement model is satisfactory.

Table 2. Discriminant validity Data source (author's data analysis)

\begin{tabular}{|c|c|c|c|c|c|c|c|c|c|}
\hline Construct & Mean & Standard deviation & INT & ATT & SIN & SDN & PBC & ALT & GSI \\
\hline INT & 3.95 & 0.86 & 0.789 & & & & & & \\
\hline ATT & 4.12 & 0.81 & 0.548 & 0.775 & & & & & \\
\hline SIN & 3.58 & 0.84 & 0.403 & 0.505 & 0.768 & & & & \\
\hline PBC & 3.42 & 0.81 & 0.508 & 0.601 & 0.627 & 0.555 & 0.789 & & \\
\hline ALT & 4.05 & 0.93 & 0.604 & 0.619 & 0.526 & 0.618 & 0.574 & 0.784 & \\
\hline GSI & 3.69 & 0.88 & 0.624 & 0.613 & 0.716 & 0.508 & 0.602 & 0.422 & $\mathbf{0 . 7 9 8}$ \\
\hline
\end{tabular}

Diagonals in bold signify the square root of the AVE while the other figures depict the correlations 


\section{Structural model assessment}

The assessment of the structural model includes the examination of the common method bias, the $\mathrm{R}^{2 \text {, the }} \mathrm{Q}^{2}$ and the evaluation of the path coefficients (Hair et al., 2019). The VIFs for the constructs of the study ranged from 1308 to 2.540 suggesting that that the model is free of CMD. The $\mathrm{R}^{2}$ shows the proportion of variance in the dependent variable that can be explained by the independent variable. $\mathrm{R}^{2}$ values are 0.25 (weak), 0.50 (moderate) and 0.75 (substantial) (Kock, 2011). The original TPB model accounted for $38.8 \%$ of the variance in intention. The extended model explained $45.1 \%$ of the variance. This indicates that inclusion of two constructs (altruism and green selfidentity) increased the explained variance by $6.9 \%$. To determine if the model adequately explains the empirical data, the goodness of fit test (GOF) was used. The values of the GOF range from 0 to 1 with 0.10 considered small, 0.25 medium and 0.36 large. The GOF is 0.537 suggesting that the empirical data satisfactorily fits the model and has a good predictive power in comparison to baseline values. In addition to the size of the $\mathrm{R}^{2}$, a recommended test is the predictive relevance of the model $\left(\mathrm{Q}^{2}\right)$. The two prediction techniques for the $\mathrm{Q}^{2}$ are the cross validated communality and cross validated redundancy with Chin (2010) suggesting the use of the former. A $\mathrm{Q}^{2}>0.5$ is considered a predictive model and a $\mathrm{Q}^{2}$ of 0.66 obtained by this study is indicative of a highly predictive model. The effect size $\left(\mathrm{f}^{2}\right)$ shows the effect of one construct on another construct and values are 0.02 (small), 0.15 (medium) and 0.35 (large). The effect size, $f^{2}$, ranged from 0.108 to 0.136 indicating that the effect sizes of different endogenous constructs on the exogenous constructs ranged from small to medium. The results path coefficients and T-statistics and mediation are depicted in tables 3 and 4 .

Table 3. Path coefficient and T-statistics Data source (author's data analysis)

\begin{tabular}{|l|c|c|c|}
\hline \multicolumn{1}{|c|}{ Hypothesised path } & Standardised Beta & T-statistics & Decision \\
\hline H1 ATT $\rightarrow$ INT & 0.311 & $4.088^{*}$ & Accepted \\
\hline H2 SIN $\rightarrow$ INT & 0.127 & $2.580^{* *}$ & Accepted \\
\hline H3 SDN $\rightarrow$ INT & 0.104 & $2.305^{* *}$ & Accepted \\
\hline H4 PBC $\rightarrow$ INT & 0.247 & $3.802^{*}$ & Accepted \\
\hline H5 ALT $\rightarrow$ INT & 0.184 & $3.201^{* *}$ & Accepted \\
\hline H6 ALT $\rightarrow$ ATT $\rightarrow$ INT & Partial mediation $($ table 4 & - & Accepted \\
\hline H7 GSI $\rightarrow$ INT & 0.118 & $2.404^{* *}$ & Accepted \\
\hline H8 GSI $\rightarrow$ ATT $\rightarrow$ INT & No mediation table 4 & - & Rejected \\
\hline P $<0.01 * * *<0.05$ & &
\end{tabular}

Table 4. Mediation results Data source (author's data analysis)

\begin{tabular}{|c|c|c|c|c|c|c|}
\hline \multirow[t]{2}{*}{ Mediation path } & \multirow[t]{2}{*}{ Indirect effect } & \multirow[t]{2}{*}{ Total effect } & \multicolumn{2}{|c|}{ Bootstrap 95\% } & \multirow[t]{2}{*}{ Decision } & \multirow[t]{2}{*}{ VAF } \\
\hline & & & Bias-corrected & Percentile & & \\
\hline H6 ALT $\rightarrow$ ATT $\rightarrow$ INT & $0.092 * *$ & $0.271 * *(4.885)$ & {$[0.042 ; 0.110]$} & {$[0.044 ; 0.116]$} & Accepted & $33.95 \%$ \\
\hline $\mathrm{H} 8 \mathrm{GSI} \rightarrow \mathrm{ATT} \rightarrow \mathrm{INT}$ & 0.024 & $0.114 \quad(1.183)$ & {$[0.061 ; 0.124]$} & {$[0.066 ; 0.129]$} & Rejected & \\
\hline
\end{tabular}

$* \mathrm{P}<0.01 ; * *<0.05$

The results H1 $(\beta=0.311, \mathrm{~T}=4.088, \mathrm{p}<.001), \mathrm{H} 2(\beta=0.127, \mathrm{~T}=2.580, \mathrm{p}<.005), \mathrm{H} 3(\beta=0.104, \mathrm{~T}=2.305, \mathrm{p}<.005), \mathrm{H} 4(\beta=0.247, \mathrm{~T}=$ $3.802, \mathrm{p}<.001), \mathrm{H} 5(\beta=0.184, \mathrm{~T}=3.201, \mathrm{p}<.005), \mathrm{H} 7 \quad(\beta=0.118, \mathrm{~T}=2.404, \mathrm{p}<.005)$ support significant positive direct relationships between attitude, subjective injunctive norms, subjective descriptive norms, perceived behavioural control, altruism and green selfidentity and consumer intention to stay in green hotels. Thus, hypothesis one, two, three four, five and seven are accepted. Mediation considers the presence of an intermediate variable or mechanism that transmits the effect of an antecedent variable to an outcome According to Nitzl et al. (2016), mediation involves two main phases: (1) the significance of indirect effects and their magnitude should be determined. (2) the definition of the type of effect and/or mediation that exist. Thus the existence of full or partial me diation (which can be complementary or competitive partial mediation). In a complementary partial mediation, both the direct and indirect effects point in the same direction (e.g. both are positive or negative) while in a competitive partial mediation, they point in different directions (e.g. one is positive and one is negative). The Variance Accounted For (VAR) can be used to determine the existence of full or partial mediation and a mediation is close to zero if the VAF value is less than $20 \%$. If the VAF value is between $20 \%$ and $80 \%$ (partial mediation) and VAF value above $80 \%$ full mediation (Hair et al. 2019), Table 5 depicts the results of mediation. The indirect path between altruism, attitude and intention is positive and significant $(\beta=0.271, \mathrm{~T}=4.885, \mathrm{p}<.005)$. In addition, the VAF is $33.95 \%$. Thus a complementary mediation partial is confirmed and hypothesis six is supported. The indirect path between altruism, attitude and intention is not significant $(\beta=0.114, \mathrm{~T}=1.183, \mathrm{p}>0.05)$. Therefore, there is no mediation and hypothesis eight is rejected.

The findings support the applicability of the TPB model in predicting consumer intention to stay in green hotels in South Africa. Attitude, subjective injunctive norms, subjective descriptive norms and perceived behavioural control have significant positive relationship with consumer intention to stay in a green hotel. The results indicated that individuals with a positive attitude towards green hotels are likely to stay in green hotels. The findings showed that the effects of subjective injunctive and descriptive norms on the intention to stay in green hotels are significantly positive. The results indicated that the opinions of people that are important to the consumer can influence the intention to visit green hotels. In addition, the findings support a significant positive relationship between perceived behavioural control and intention to visit green hotels. This suggests that if individuals have the opportunities a nd resources to choose green hotels, will be more inclined to stay in green hotels. The findings of this study are supported by the results of prior empirical studies. Han et al. (2010), Teng et al. (2015) and Verma and Chandra (2017) find that the three TPB constructs positively affect consumer intention to visit green hotels and that the TPB model has a good predictive power. Nimri et al. (2019) also find a significant positive relationship between travellers' injunctive norms and intentions with the effect of descriptive norms being insignificant. However, the findings of the study by Doran and Larsen (2016) on intention to choose eco-friendly travel options indicated a significant positive association between descriptive and injunctive norms and behavioural intention.

The study added two constructs altruism and green self-identity to extend the TPB. Also, the mediating effects of attitude in the relationship between these two constructs and intention were examined. The findings indicated a significant positive relation ship between altruism and the intention to stay in green hotels and are consistent with the results of previous empirical studies. Ojedoku n (2011) finds a significant positive relationship between altruism and responsible environmental behaviour while Teng et al. (2015) used altruism to extend the TPB and find a significant positive relationship between the construct and intention to visit green hotels. The findings of the study also support a significant positive relationship between green self-identity and intention. This suggests that individuals that perceive themselves as environmentalists are likely to stay in green hotels. Studies by Carfora et al. (2017) and Qasim et al . (2019) also 
find a significant positive relationship between green self-identity and intention and behaviour. The findings of the study indicate that attitude partially mediates the relationship between altruism and intention to visit green hotels. Ojedokun and Balogun (2010) find that attitude towards littering partially mediates the relationship between altruism and responsible environmental behaviour. The mediating effect of attitude in the relationship between green self-identity and intention is insignificant. The findings of this study is supported by Sparks and Shepherd (1992) that self-identity can contribute to behavioural intention independently of attitude and that the influence of self-identity on intention is not mediated through evaluative attitude. Finally, the findings of the study support the view by Ajzen (1991) that the addition of appropriate constructs can improve the explanatory power of the TPB.

\section{CONCLUSION}

The study investigated the predictors of consumer intention to stay in green hotels in South Africa by extending the TPB. The res ults indicated significant positive relationships between attitude, subjective injunctive and descriptive norms, perceived behavioural control, altruism and green self-identity and consumer intention to visit green hotels. The mediating effect of attitude in the relationship between altruism and intention is significant. Theoretically, the research confirms the applicability of the TPB model in predicting the intenti on to stay in green hotels and the usefulness of the extended model that included altruism and green self-identity. The results of the study indicated that ttitude, subjective injunctive norms and perceived behavioural control positively affect intention to stay in green hotels. To improve attitude, the hospitality industry and hotel management should create awareness about the contribution of green hotels to environmental protection through electronic, social and print media. Green hotels should provide information to customers about the amount of resources that are been saved by their activities and how they are protecting the environment.

This can help to shift the behaviour of consumers towards sustainable consumption. Previous consumers that have visited green hotels should be used in marketing campaigns various media platforms to share the benefits and encourage potential visitors. To improve perceived behavioural control, green hotels should be made affordable to consumers as there is the perception that they are significantly more expensive than conventional ones. In addition, creating the impression that green hotels are family friendly with facilities that are geared toward family comfort can help to improve subjective norms. Altruism and green self-identity also influence the intention to stay in green hotels. Therefore, governments, non-governmental organisations and media should continue to emphasise the need for people to protect the environment for today and future generations. This can help to create altruistic feelings and promote green identity in individuals. The study has some limitations and also proposes some areas for further study. The study focused on the predictors of intention and not actual behaviour. Intention does not always predict behaviour and other studies can investigate the determinants of green hotel staying behaviour. The inclusion of other personal variables such as response efficacy, anticipated guilt and moral norms can help to improve the explanatory power of the TPB model in the context of the intention to stay in green hotels.

\section{Acknowledgement}

The research was sponsored by the Department of Business Management, University of Limpopo ref BMAN 30/19.

\section{REFERENCES}

Ajzen, I., \& Fishbein, M. (1980). Understanding attitudes and predicting social behaviour. Prentice Hall, New Jersey, United States of America.

Ajzen, I (1991). The theory of planned behaviour. Organizational Behaviour and Human Decision Processes, 50, 179-211. https://doi:10.1016/07495978(91)90020-T

Ali, S.H., \& Oliviera, J.A. (2018). Pollution and economic development: an empirical research review. Environmental Research Letters, 13(1), 1-14. https://doi.org/10.1088/1748-9326/aaeea7

Alipour, H., Safaeimanesh, F., \& Soosan, A. (2019). Investigating Sustainable Practices in Hotel Industry-from Employees' Perspective: Evidence from a Mediterranean Island. Sustainability, 11(23), 5-30. https://doi.org/10.3390/su11236556

Alvarado, R., \& Toledo, E. (2017). Environmental degradation and economic growth: evidence for a developing country. Environment, Development and Sustainability, 19(1), 1205-1218. https://doi. 10.1007/s10668-016-9790-y

Barbarossa, C., De Pelsmacker, P., \& Moons, I. (2017). Personal Values, Green Self-identity and Electric Car Adoption. Ecological Economics, 140(C),190200. https://doi: 10.1016/j.ecolecon.2017.05.015

Burke, M., Ockwell, D., \& Whitmarsh, L. (2018). Participatory arts and affective engagement with climate change: The missing link in achieving climate compatible behaviour change. Global Environmental Change, 49, 95-105. https://doi.org/10.1016/j.gloenvcha.2018.02.007

Carlo, G., Okun, M.A., Knight, G., \& de Guzman, M.R. (2005). The interplay of traits and motives on volunteering: Agreeableness, extraversion and prosocial value motivation. Personality and Individual Differences, 38(6), 1293-1305. https://doi.org/10.1016/j.paid.2004.08.0

Carfora, V., Caso, D., Sparks, P., \& Conner, M. (2017). Moderating effects of pro-environmental self-identity on pro-environmental intentions and behaviour: A multi-behaviour study. Journal of Environmental Psychology, 53, 92-99. https://doi.org/10.1016/j.jenvp.2017.07.001

Chan, E., Okumus, F., \& Chan, W. (2018). Barriers to Environmental Technology Adoption in Hotels. Journal of Hospitality and Tourism Research, 42(5), 829-852. https://doi.org/10.1177/1096348015614959

Charng, HW., Piliavin, JA., \& Callero, P. (1988). Role identity and reasoned action in the prediction of repeated behaviour. Social Psychology Quarterly, 51(4), 303-317. https://doi.org/10.2307/2786758

Chen, Y., \& Chen, Y. (2012). The Advantages of Green Management for Hotel Competitiveness in Taiwan: In the Viewpoint of Senior Hotel Managers. Journal of Management and Sustainability; 2(2), 211-218. https://doi:10.5539/jms.v2n2p211

Chen, M., \& Tung, P. (2014). Developing an extended Theory of Planned Behavior model to predict consumers' intention to visit green hotels. International Journal of Hospitality Management, 36, 221-230. https://doi.org/10.1016/j.ijhm.2013.09.006

Chin, W. (2010). How to Write Up and Report PLS Analyses. In the Handbook of Partial Least Squares, (pp 655-690). Springer, Heidelberg. DOI https://doi.org/10.1007/978-3-540-32827-8_29

Chivandi, A., Samuel, O., \& Muchie, M. (2020). African cultures as tourism innovative capability in South African tourism sector: a Gauteng Province perspective. GeoJournal of Tourism and Geosites, 30(2spl), 782-788. https://doi.org/10.30892/gtg.302spl19-523

Constant, K. (2019). Environmental policy and human capital inequality: A matter of life and death. Journal of Environmental Economics and Management, 97, 134-157. https://doi.org/10.1016/j.jeem.2018.04.009

Doran, R., \& Larsen, S. (2016). The Relative Importance of Social and Personal Norms in Explaining Intentions to Choose Eco-Friendly Travel Options. International Journal of Tourism Research, 18(2), 159.166. https://doi.org/10.1002/jtr.2042

Farrow, K., Grolleau, G., \& Ibanez, L. (2017). Social Norms and Pro-environmental Behaviour: A Review of the Evidence. Ecological Economics, 140 (C), 113. https://doi 10.1016/j.ecolecon.2017.04.017

Folarin, O., \& Adeniyi, O. (2020). Does Tourism Reduce Poverty in Sub-Saharan African Countries? Journal of Travel Research, 59(1), 140-155. https://doi.org/10.1177/0047287518821736 
Gatersleben, B., Murtagh, N., \& Murtagh, W. (2014). Values, identity and pro-environmental behaviour. -environmental behaviour. Contemporary Social Science: Journal of the Academy of Social Sciences, 9(4), 1-18.

Granberg, D., \& Holmberg, S. (1990). The intention-behaviour relationship among U.S. and Swedish voters. Social Psychology Quarterly, 53(1), 44-54. https://doi.org/10.2307/2786868

Han, H., Hsu, L.T., \& Sheu, C. (2010). Application of the Theory of Planned Behaviour to green hotel choice: Testing the effect of environmental friendly activities. Tourism Management, 31(3), 325-334. https://doi:10.1016/j.tourman.2009.03.013

Hair, J., Risher, J., Sarsstedt, M., \& Ringle, C. (2019). When to use and how to report the results of PLS-SEM. European Business Review, 31(1), 2-24. https://doi I: 10.1108/EBR-11-2018-0203

Honey, M., \& Rome, A. (2011). Protecting Paradise: Certification Programs for Sustainable Tourism and Ecotourism. Institute for Policy Studies, Washington, United States of America.

Hoogendoorn, G., Grant, B., \& Fitchett, J. (2015). Towards green guest houses in South Africa: The case of Gauteng and KwaZulu-Natal. South African Geographical Journal, 97(2),123-138. https://doi.org/10.1080/03736245.2015.1028977

Karim, R., \& Islam, M. (2020). Assessing customer demand and customer satisfaction through social and environmental practices in the hotel sector of Bangladesh. GeoJournal of Tourism and Geosites, 30(2), 843.851. https://doi 10.30892/gtg.3 3002 2s sp pl 1009 9-5 51 13 3

Kock, N. (2011). Using WarpPLS in e-collaboration studies: An overview of five main analysis steps. International Journal of e-Collaboration, 6(4), 1-11. https://doi: 10.4018/jec.2010100101

Kim, S., Lee, K., \& Fairhurst, A. (2017). The review of "green" research in hospitality, 2000-2014: Current trends and future research directions. International Journal of Contemporary Hospitality Management, 29(1), 226-247. https://doi: 10.1108/IJCHM-11-2014-0562

Kurniawati, E., Sumarmi, \& Aliman, M. (2020). participation of green environmental group and ulur-ulur local wisdom on buret lake ecotourism management in karst area of tulungagung, indonesia. GeoJournal of Tourism and Geosites, 30(2), 889-895. https://doi.org/10.30892/gtg.302spl15-519

Lalot, F., Quiamzade, A., Falomir-Pichastor, J., \& Gollwitzer, P. (2019). When does self-identity predict intention to act green? A self-completion account relying on past behaviour and majority-minority support for pro-environmental values. Journal of Environmental Psychology 61, 79-92. https://doi: 10.1016/j.jenvp.2019.01.002

Manosuthi, N., Lee, J., \& Han, H. (2020). Predicting the revisit intention of volunteer tourists using the merged model between the theory of planned behaviour and norm activation model. Journal of Travel and Tourism Marketing, 37(4), 510-532. https://doi.org/10.1080/10548408.2020.1784364

Mbasera, M., du Plessis, E., Saayman, M., \& Kruger, M. (2018). Environmentally-friendly practices in hotels. Acta Coomercii, 16(1), 1-8. https://doi.org/10.4102/ac.v16i1.362

Nimri, R., Patiar, A., Kensbock, S., \& Jin, X. (2019). Consumers' Intention to Stay in Green Hotels in Australia: Theorization and Implications. Journal of Hospitality and Tourism Research, 44(1), 149 -168. https://doi.org/10.1177/1096348019862602

Nguyen, T., Lobo, A., \& Greenland, S. (2017). The influence of Vietnamese consumers' altruistic values on their purchase of energy efficient appliances. Asia Pacific Journal of Marketing and Logistics, 29(4), 759-777. https://doi: 10.1108/APJML-08-2016-0151

Noor, N., Shaari, H., \& Kumar, D. (2014). Exploring tourists' intention to stay at green hotel: the influences of environmental attitudes and hotel attributes. The Macrotheme Review, 3(7), 22-33.

Nitzl, C., Roldan, J.L. \& Cepeda-Carrion, G. (2016). Mediation Analysis in Partial Least Squares Path Modeling: Helping Researchers Discuss More Sophisticated Models. Industrial Management \& Data Systems, 116(9),1849-1864. https://doi: 10.1108/IMDS-07-2015-0302

Ojedokun, O.A., \& Balogun, S.K. (2010). Environmental Attitude as a Mediator of the Relationship between Self-concept, Environmental Self-Efficacy and Responsible Environmental Behaviour among Residents of High Density Areas in Ibadan Metropolis, Nigeria. Ethiopian Journal of Environmental Studies and Management, 3(2), 111-119. https://doi 10.4314/ejesm.v3i2.59834

Ojedokun, O.A. (2011). Attitude Towards Littering as a Mediator of the Relationship between Personality Attributes and Responsible Environmental Behaviour. Waste Management, 31(12), 2601-2612. https://doi: 10.1016/j.wasman.2011.08.014

Pradhan, P', Costa, L., Rybski, D., Lucht, W., \& Kropp, J. (2017). A Systematic Study of Sustainable Development Goal (SDG) Interactions. Earth 's Future, 5(11), 1169-1179 https://doi.org/10.1002/2017EF000632

Qasim, H., Yan, L., Guo, R., \& Saeed, A. (2019). The Defining Role of Environmental Self-Identity among Consumption Values and Behavioural Intention to Consume Organic Food. International Journal of Environmental Research and Public Health, 16(7), 1106-1114. https://doi: 10.3390/ijerph16071106

Rahman, M.M. (2020). Environmental degradation: The role of electricity consumption, economic growth and globalisation. Journal of Environmental Management, 253(4), 1-8. https://doi.org/10.1016/j.jenvman.2019.109742

Ryan T.A. (2017). The Role of Beliefs in Purchase Decisions: A Look at Green Purchase Behaviour and Altruism. Journal of Research for Consumers, 31, 1-11.

Shen, P. (2017). Consumption Intentions toward green restaurants: Application of theory of planned behaviour and altruism. International Journal of Management, Economics and Social Sciences, 6(3), 121-143. https://doi://hdl.handle.net/10419/171450

Sparks, P., \& Shepherd, R. (1992). Self-identity and the theory of planned behaviour: Assessing the role of identification with "green consumerism". Social Psychology Quarterly, 55(4), 388-399. https://doi //www.jstor.org/stable/2786955

Spenceley, A. (2018). Sustainable tourism certification in the African hotel sector. Tourism Review, 1, 1-15. https://doi 10.1108/TR-09-2017-0145

Suki, N., \& Suki, N. (2015). Consumers' environmental behaviour towards staying at a green hotel. Management of Environmental Quality an International Journal, 26(1), 103-117. https://doi:10.1108/MEQ-02-2014-0023

Schwartz, S.H. (1977) Normative influences on altruism. Advances in experimental social psychology, 10, 221-279. https://doi.org/10.1016/S00652601(08)60358-5

Tan, LL., Aziz NA., \& Ngah, AH. (2020). Mediating effect of reasons on the relationship between altruism and green hotel patronage intention. Journal of Marketing Analytics, 8(1), 18-30. https://doi: 10.1057/s41270-020-00067-7

Teng, Y., Wu, K., \& Liu, H. (2015). Integrating Altruism and the Theory of Planned Behaviour to Predict Patronage Intention of a Green Hotel. Journal of Hospitality \& Tourism Research, 1(5), 20-29. https://doi.org/10.1177/1096348012471383

Wolff, K., Nordin, K., Brun, W., Berglund, G.. \& Kvale, G. (2011) Affective and Cognitive Attitudes, Uncertainty Avoidance and Intention to Obtain Genetic Testing: An Extension of the Theory of Planned Behaviour. Psychology \& Health, 26, 1143-1155. https://doi.org/10.1080/08870441003763253

Verma, V., \& Chandra, B. (2017). Intention to Implement Green Hotel Practices: Evidence from Indian Hotel Industry. International Journal of Management Practice, 11(1), 1-11. https://doi: 10.1504/IJMP.2018.10008645 